ISSN 0258-7122 (Print), 2408-8293 (Online)

Bangladesh J. Agril. Res. 44(3): 409-426, September 2019

\title{
IMPACT OF MULTI-CROP PLANTER BUSINESS ON SERVICE PROVIDERS' LIVELIHOOD IMPROVEMENT IN SOME SELECTED AREAS OF BANGLADESH ${ }^{1}$
}

\author{
M. A. M. MIAH ${ }^{1}$, M. E. HAQUE ${ }^{2}$, AND R. W. BELL ${ }^{3}$
}

\begin{abstract}
The custom hiring of the Versatile Multi-crop Planter (VMP) is a profitable enterprise for Local Service Providers (LSP) that could improve their household livelihood but the impacts have not yet been assessed in Bangladesh. In this study, we assessed the use pattern and profitability of custom-hiring the VMP, and its impacts on LSPs' livelihood. A total of 18 LSP were purposively selected from Rajshahi, Thakurgaon, Mymensingh, and Rajbari districts for this study. The study revealed that LSPs effectively utilized VMP and 2-wheel tractor (2WT) for 4-6 months. They earned Tk. 1,42,434 (with incentive on VMP) and Tk. 1,36,134 (without incentive) per year as net income. The average payback periods were 0.72 and 0.98 years with and without incentive, respectively. The annual break-even of a VMP use was 7.79 ha. The LSPs reported a considerable cash (annual income increased by $34.9 \%$ ), and capital enhancement, e.g., land holdings $(8.3 \%)$, value of livestock $(11.2 \%)$, dwelling houses $(36.6 \%)$, household furniture $(19 \%)$, and modern amenities $(45.5 \%)$. The increased incomes from VMP custom hiring were mostly spent on nutritious food, land mortgage-in, and dwellings. The LSPs reported minor challenges such as being unable to use this machine in the wetland condition (61 $\%$ ), no seating arrangement on the machine during operation in small plots (56 $\%)$, long time taken to complete sowing due to narrow planting width per pass (50 \%), farmers' skepticism about the planting machine as it is still new technology (44\%), and lack of skilled drivers (17\%). Financial support and technical assistance should be made available by the government for LSPs and local manufacturers to accelerate greater adoption of the VMP.
\end{abstract}

Keywords: break-even point, net return, payback period, planting machine, planter custom hire

\section{Introduction}

Mechanization of tillage by 2-wheel tractor (2WT, or power tiller) spread in Bangladesh since the mid-1990s replacing manual and animal-draught tillage. Small farm sizes restrict the purchase and utility of 4-wheel tractors here and in many parts of Asia and Africa. Hence the 4-wheel tractor options for mechanized planting are not available in the regions where $2 \mathrm{WT}$ are the predominant form of

${ }^{1}$ Principal Scientific Officer, Agricultural Economics Division, Bangladesh Agricultural Research Institute (BARI), Joydebpur, Gazipur-1701, ${ }^{2}$ Adjunct Associate Professor, Murdoch University, Australia, ${ }^{3}$ Professor, Murdoch University, Australia. 
mechanized tillage (Haque et al., 2017). In Bangladesh, shortage of hired-labour and substantial increases of crop production cost are leading to greater interest in mechanization in smallholder agriculture (Bell et al., 2017).

Presently, the 2WT are mostly operated in fully rotary tillage mode (Haque et al., 2016). However, there are promising developments in minimum soil disturbance planters for 2WT (Johansen et al., 2012; Haque et al., 2016). The one widelyused option in Bangladesh to date, the Single Pass Shallow Tillage planter (SPST) (also known as the Power Tiller Operated Seeder, PTOS), involves shallow full rotary tillage of the top soil (up to $0.04 \mathrm{~m}$ ) (Wohab et al., 2007; Roy et al., 2009). Full tillage such as this can be harmful to soil structure and soil health (Johansen et al., 2012).

Bell et al. (2017) and Sarker et al. (2012) concluded that the field performances of minimum soil disturbance planters were much better than conventional full tillage systems. Different crops can be established and grown successfully through planting with minimum soil disturbance (Haque et al., 2018, Bell et al., 2017, Barma et al., 2014; Alamgir et al., 2015). Crop establishment using minimum soil disturbance planters reduces operational costs; including machinery, labour, and fuel, while increasing yields and efficiency of natural resource use (Haque et al., 2018, Bell et al., 2017, Roy et al., 2009). Islam et al. (2010) found that $41-43 \%$ less irrigation water was used for crop established by VMP planting as compared to a traditional full tillage by $2 \mathrm{WT}$. In this context, minimum soil disturbance is becoming increasingly important in decreasing crop production cost, soil health improvement, and overcoming the problems of declining agricultural productivity in developing countries (Johansen et al. 2012).

The cropping intensity of Bangladesh is increasing progressively over time and most small holders are now growing two or more crops per field in a year (BBS, 2018; BER, 2018). Over a 5-year cycle due to changing profitability of crops, farmers cultivate 4-6 crops with diverse seed sizes, seed rate, row spacing, fertilizer rates, and seed depth. Hence a planter for such diverse cropping systems needs to handle such variations in settings as well providing for different crop establishment options according to farmer demand, i.e. strip planting, zero planting, bed planting, single pass shallow tillage and planting, even conventional full tillage. The LSP of the planter also need to be able to hire out their planter for business as much of the year as possible to justify the investment cost. There are a number of other criteria and challenges that would need to be satisfied by potential purchasers of a planter. The VMP was developed in Bangladesh in 2008 to meet the above criteria and successfully establish a diverse range of crops (Haque et al., 2017). It has capability for seeding and fertilizing with fluted roller or vertical plate meters in lines for single-pass shallow-tillage, strip planting, zero tillage and bed planting. Most of the grain seeds including wheat, paddy, maize, jute, pulses, oilseeds etc. can be sown in lines by the VMP (Bell et al., 2017). 
The ACIAR funded LWR-2010-080 Project invented new methods to create demand and accelerate farmer testing of planting services by VMP that attract new LSPs and farmers while the technology was still unfamiliar to them. Each and every new VMP owner received a once-only planting incentive @Tk. 300/per bigha for up to 30 bigha of planting. This model was applicable for the purchase of VMP alone. The Project conducted audits to verify that planting was completed by the LSP before the incentive was approved. The audits were also used to identify cases of poor planting performance or planter faults so that these could be corrected. Previous experience with LWR/2010/080 suggests that incentive support helps the LSP to quickly build a client base for future business, and reduces the risk for first time users of the VMP planting service so that they can gain confidence in its reliability and cost effectiveness. These plantings also serve as demonstrations to advertise to local farmers the effectiveness of the planting.

The LSPs are conducting business with smallholders on a custom hire basis with different implements. The custom hiring of PTOS was highly profitable at farm level (Miah et al., 2010) and improved LSPs livelihood (Miah and Haque, 2015). However, the impact on LSPs livelihood using VMP was not assessed yet. In this paper, we will report the outcomes of a study to assess the livelihood of LSPs using the VMP in 2016.

\section{Objectives of the study}

The specific objectives of the study were:

(i) To estimate the profitability of the custom hiring of the VMP for seeding operations on farms;

(ii) To assess the impacts of VMP on LSP's livelihood improvement; and

(iii) To determine the problems that LSPs reported during VMP operation.

\section{Materials and Methods}

\section{Study Area Selection}

The project "Overcoming agronomic and mechanization constraints to development and adoption of conservation agriculture in diversified rice-based cropping in Bangladesh" was funded by ACIAR since April 2012 to March 2017. In this project, a total of 47 VMPs were purchased by interested LSP of Rajshahi, Thakurgaon, Mymensingh and Rajbari districts during 2012-16. Therefore, the above mentioned districts were purposively selected for the present study.

\section{Sampling Technique and Period of Study}

In order to evaluate the impact of VMP operations at farm level, a total of 18 LSP of VMP who provided at least 2-years of planting services to the farmers 
were purposefully selected from the aforesaid districts and interviewed for this study. Data and information were gathered from selected LSPs of VMP through conducting household survey using pre-tested questionnaire and the interview was conducted during December, 2016.

\section{Analytical Technique}

Calculation of costs and return: In estimating the profitability of VMP operation at farm level, different cost items such as fuel and oil, wages for a driver, repair and maintenance, spare parts, depreciation, and interest on investment were calculated based on field level data. The costs of depreciation for 2WT or power tiller (add the \% used), VMP and machinery shed were assumed to be linear over time. In the study area, the 2WT was not used throughout the year with VMP. However, 12 months were considered in estimating the costs of depreciation and interest on investment for both VMP and 2WT in this study.

The profitability of VMP for planting operation at farm level was estimated both with and without planting incentive. We calculated the breakeven point of VMP operation for the LSP based on fixed cost, variable cost and gross income which were calculated from farm level data. At break-even point, the revenues of the business are equal its total costs and its contribution margin equals its total fixed costs. The break-even on the basis of land area (ha) planted by VMP was estimated using the following equation.

Breakeven land area (ha) planted by VMP $=\frac{\mathrm{FC}}{\mathrm{P}-\mathrm{VC}}$

Where, FC is total fixed cost, $\mathrm{P}$ is the gross income, and $\mathrm{VC}$ is total variable cost

Calculation of impacts: The impacts of VMP on the livelihoods of LSPs were assessed through analyzing 'Before' and 'After' socio-economic standings of the LSPs. It means that we asked the respondent to report what was their situation before and after operating the VMP. Data regarding land holdings, livestock resources, yearly household income, ownership of farm equipment, household assets, liability status, and food intake were analyzed and compared for measuring the impacts of VMP service on its LPS's livelihoods. The values of different household assets were collected based on present value. For example, the house of a service provider was built five years back with Tk.50000 but due to price hiking; the present value of this house is Tk.70000 which was used for reporting. Besides, if that farmer invests extra money for renovation and/or extension of the house that amount was also added to the present value in this report. Two-tail t-test was employed to determine significant difference between two periods. 


\section{Results and Discussion}

\section{Socioeconomic Profile of VMP Local Service Providers}

There are numerous interrelated and constituent attributes that characterize a person and these profoundly influence development behavior. Some related socioeconomic characteristics of the LSPs of VMP are shown in Table 1.

Age is an important factor that may influence an entrepreneur's decision to operate the VMP as a custom hiring business. The average age of the respondents was 34 years ranging from 22 to 58 years. They were grouped into four categories based on their level of education. About $56 \%$ of them completed primary level of education, followed by $22 \%$ of higher secondary levels. Only $11 \%$ of LSPs completed degree-level education. The average length of experience of LSP in VMP operations was three years ranging from two to seven years. Most of them had two years experience. All of the respondents bought VMP by their own cash with planting incentive from the LWR-2010-080: Conservation Agriculture Project. Many LSP owned a number of farm implements namely 2WT (power tiller), power thresher, shallow tube well (STW), sprayer, and hand weeder that were mostly used for renting out to others for earning cash income. All of sampled VMP service providers owned 2WT and sprayer, $72 \%$ owned power thresher, 50 $\%$ owned STW and $22 \%$ owned hand weeder (Table 1). Hence none of the LSP were totally reliant on the VMP for earning income by custom hiring. Income from the other custom hiring services is not reported here.

Table 1. Socioeconomic profile of VMP local service providers in the study areas

\begin{tabular}{lcc}
\hline \multicolumn{1}{c}{ Items } & No. of respondent & Mean \\
\hline 1. Farmers' age (year) & 18 & 34.0 \\
2. Level of education (\%) & & \\
a. Primary level (Class I-V) & 10 & 55.6 \\
b. Secondary level (VI-X) & 2 & 11.1 \\
c. Higher secondary level (HSC) & 4 & 22.2 \\
d. Degree \& above & 2 & 11.1 \\
3. Experience with VMP service (\%) & & \\
a. 7 years (2010) & 2 & 11.1 \\
b. 5 years (2012) & 1 & 5.6 \\
c. 3 years (2014) & 4 & 22.2 \\
d. 2 years (2015) & 11 & 61.1 \\
4. Type of farm machinery owned (\%) & & \\
a. Versatile Multi-crop Planter (VMP) & 18 & 100 \\
b. 2-wheel tractor or power tiller & 18 & 100 \\
c. Power thresher & 13 & 72.2 \\
d. Shallow tube well & 9 & 50.0 \\
e. Sprayer & 18 & 100 \\
f. Hand weeder & 4 & 22.2 \\
\hline
\end{tabular}

Source: Field survey, 2016 


\section{Uses Pattern of VMP and 2WT at Farm Level}

The LSPs in the study areas used VMP for crop cultivation in their own land and provided custom hiring services to other farmers to plant a range of crops including wheat, maize, pulses (lentil \& mungbean), and mustard. The seedlings of Boro paddy were also transplanted in strip-based non-puddled condition. The strips were made by VMP however, transplanting of rice seedlings was done manually. On the other hand, the LSPs also used 2WT for tillage in their own land and rented out it to other farmers for tillage operation. On an average, each LSP accomplished 21.7 ha of crop establishment (e.g., land preparation, seeding in line, fertilizing near to seeded line and land leveling) by VMP, and a 2WT completed 36.4 ha for only tillage operation in 2015-16. The highest area of land was planted through VMP in Rajshahi district followed by Thakurgaon district. Again, the highest tillage was done by 2WT in Rajshahi district followed by Rajbari and Mymensingh district. The LSPs of Rajbari and Mymensingh districts used VMPs for their own crop cultivation purposes and did not provide any tillage service to other farmers. Similarly, two LSPs of Thakurgaon district did not provide any VMP service to other farmers during 2015-2016 (Table 2).

Table 2. District-wise area planted by VMP and 2WT during 2015-2016

\begin{tabular}{l|c|c|c|c|c}
\hline \multirow{2}{*}{ District } & $\begin{array}{c}\text { No. of } \\
\text { VMP/2WT } \\
\text { studied }\end{array}$ & \multicolumn{2}{|c|}{$\begin{array}{c}\text { Land area planted } \\
\text { by VMP (ha) }\end{array}$} & \multicolumn{2}{|c}{$\begin{array}{c}\text { Land area tilled } \\
\text { by 2WT (ha) }\end{array}$} \\
\cline { 3 - 6 } & & Total area & Average area & Total area & Average area \\
\hline Rajshahi & 11 & 305.8 & 27.8 & 469.6 & 42.7 \\
Thakurgaon & 4 & 77.8 & 19.5 & 78.5 & 19.6 \\
Rajbari & 2 & 5.5 & 2.8 & 78.2 & 39.1 \\
Mymensingh & 1 & 1.9 & 1.9 & 29.4 & 29.4 \\
All area & 18 & 391.0 & 21.7 & 655.7 & 36.4 \\
\hline
\end{tabular}

Source: Field survey, 2016

The sampled LSPs provided VMP services for 4 months in a year (Fig-1). The period from October to November was the peak season of VMP service since most of the Rabi crops are sown within these periods. By contrast, the periods from April to September and January to February was treated as lean periods for VMP service. In the June-July period, 2WT was used for puddling the lands for T. Aman seedling transplantation. 2WTs were also widely used in December for initial tillage of the land for Boro rice seedling transplantation (Fig-1). 


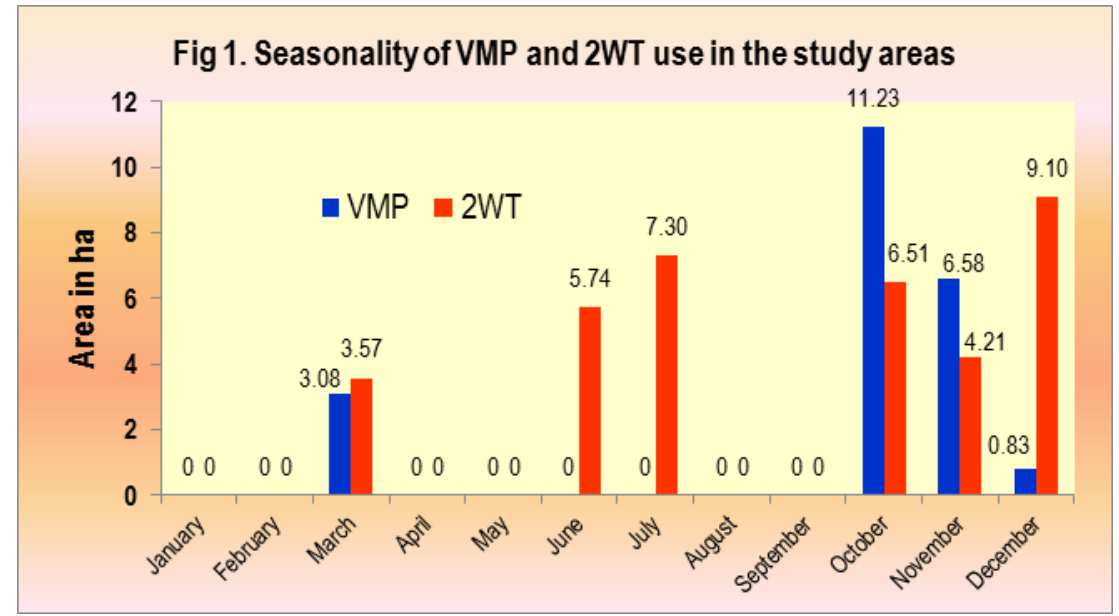

\section{Benefit-Cost Analysis of VMP Operations}

The total costs of VMP operations with and without planting incentive for VMP were Tk.1,41,855 and Tk. 1,48,155, respectively. In present situation (with planting incentive), the share of $\mathrm{VC}$ and $\mathrm{FC}$ were $84.5 \%$ and $15.5 \%$, respectively. Among cost items, the highest cost was for fuel and oil $(70.2 \%)$ followed by driver's wage $(11.3 \%)$ and interest on investment to purchase the machinery $(8.7 \%)$.

LSPs pointed out that the renting out of VMP services to other farmers was a profitable business in the study areas. The average area under land preparation and seed sowing by VMP per year ranged from 1.9 ha to 57.8 ha with an average of 21.7 ha. Again, the average area of full tillage with 2WT was estimated at 36.4 ha per year. The custom hiring charge of VMP in the last year ranged from Tk. 2,964 to Tk. 3,705 per ha with an average of Tk. 3,273 per ha. By comparison, the average per ha custom hiring charge for $2 \mathrm{WT}$ was Tk. 5,852 for full tillage (average 2.72 tillage passes). The custom hiring charges varied in the study areas due to the extent of demand for VMP and 2WT services. Based on this information, the annual gross return received from VMP and 2WT services were calculated. The average gross return received by the LSP was Tk. 2,84,289 per year. The annual net returns over total cost were Tk. 1,44,434 and 1,36,134 with planting incentive and without planting incentive on VMP, respectively. The average benefit cost ratios (BCRs) were 2.00 and 1.92, respectively implying that VMP operations on custom hiring basis at farm level was profitable (Table 3).

The current rate of adoption of VMP at farm level was still low since VMP is in its initial stage of promotion and commercialization. However, it is hoped that the current net return and rate of return will be higher in near future when the rate of adoption will be high. 
Table 3. Benefit-Cost analysis of VMP operations at farm level

\begin{tabular}{|c|c|c|}
\hline Particular & $\begin{array}{c}\text { With planting } \\
\text { incentive on VMP }\end{array}$ & $\begin{array}{l}\text { Without planting } \\
\text { incentive on VMP }\end{array}$ \\
\hline A. Gross income (Tk/year) & $2,84,289$ & $2,84,289$ \\
\hline Average area under tillage (ha/LSP) & 58.2 & 58.2 \\
\hline $\begin{array}{l}\text { Average rental charge of } 2 \mathrm{WT} \& \\
(\mathrm{Tk} / \mathrm{ha})\end{array}$ & $4,888.81$ & 4888.81 \\
\hline B. Variable cost (Tk/year) & $1,19,816(84.5)$ & $1,19,816(80.9)$ \\
\hline Fuel and oil & $99,616(70.2)$ & $99,616(67.2)$ \\
\hline Wage for driver & $15,968(11.3)$ & $15,968(10.8)$ \\
\hline Repair and maintenance & $1,521(1.1)$ & $1,521(1.0)$ \\
\hline Spare parts & $2,711(1.9)$ & $2,711(1.8)$ \\
\hline C. Fixed cost (Tk/year) & $22,039(15.5)$ & 28,339 (19.1) \\
\hline Interest on machineries ( $2 \mathrm{WT}+\mathrm{VMP})$ & $12,373(8.7)$ & $15,973(10.8)$ \\
\hline Depreciation on power tiller ( $2 \mathrm{WT}$ ) & $6,580(4.6)$ & $6,580(4.4)$ \\
\hline Depreciation on VMP & $2,700(1.9)$ & $5,400(3.6)$ \\
\hline Depreciation on machinery shed & $386(0.3)$ & $386(0.3)$ \\
\hline D. Total cost (Tk/year) & $1,41,855(100)$ & $1,48,155(100)$ \\
\hline E. Gross margin (Tk/year) & $1,64,473$ & $1,64,473$ \\
\hline F. Net income (Tk/year) & $1,42,434$ & $1,36,134$ \\
\hline \multicolumn{3}{|l|}{ G. Rate of return $(\mathrm{BCR})$} \\
\hline Over variable cost & 2.37 & 2.37 \\
\hline Over total cost & 2.00 & 1.92 \\
\hline H. Payback period of VMP (year) & 0.72 & 0.98 \\
\hline
\end{tabular}

Note: Figures in the parentheses are percent of total

Source: Appendix table 1

\section{Break-even Analysis of VMP Operations}

With the planting incentive, the annual fixed cost (FC), variable cost (VC) and gross revenue (GR) were estimated at Tk. 22,039, Tk. 2,060 and Tk. 4,889 per hectare respectively. Therefore, the break-even use of VMP is 7.79 ha of planting per year. Break-even point is the point where a LSP can operate the VMP with no loss or profit. Therefore, the LSP in the study area have to cultivate more than 7.79 ha of land per year to make it profitable (Fig 2). In fact their average planting area was 2.8 times higher. 


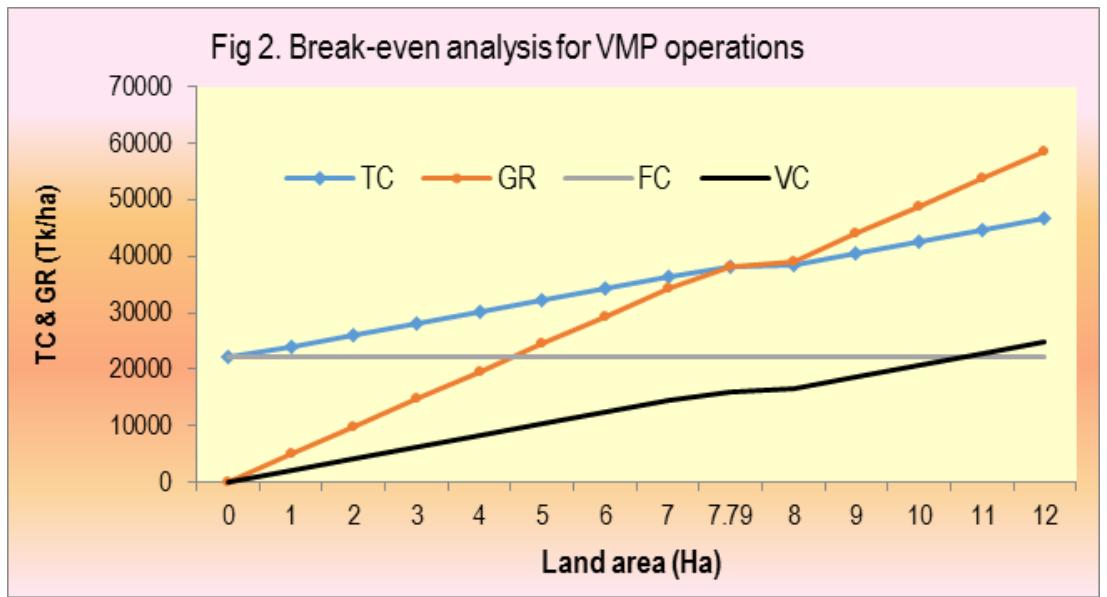

\section{Impacts of VMP on Local Service Providers' Livelihood}

Impact on land holdings: Table 4 shows that the land holding of the LSPs increased slightly along with different land categories after having VMP. Irrespective of land categories, the average holding size was increased by $8.3 \%$ mainly due to increase in mortgaged land. However, this change in land holding was insignificant.

Table 4. Status of land holdings before and after ownership of VMP

\begin{tabular}{l|c|c|c|c}
\hline \multicolumn{1}{c}{ Land category } & $\begin{array}{c}\text { After having } \\
\text { VMP }\end{array}$ & $\begin{array}{c}\text { Before having } \\
\text { VMP }\end{array}$ & Mean difference & $\begin{array}{c}\text { P(T } \text {. in ha) } \\
\text { value }\end{array}$ \\
\hline 1. Own land & 1.89 & 1.88 & $0.01(0.5)$ & 0.99 \\
2. Rented in & 0.06 & 0.06 & 0.00 & 1.00 \\
3. Rented out & 0.06 & 0.11 & -0.05 & 0.67 \\
4. Mortgaged in & 0.54 & 0.40 & $0.14(35.0)$ & 0.64 \\
5. Homestead & 0.04 & 0.04 & 0.00 & 1.00 \\
6. Orchard & 0.23 & 0.23 & 0.00 & 1.00 \\
7. Pond & 0.16 & 0.14 & $0.02(14.3)$ & 0.85 \\
*Farm size & $\mathbf{2 . 8 6}$ & $\mathbf{2 . 6 4}$ & $\mathbf{0 . 2 2} \mathbf{( 8 . 3 )}$ & \\
\hline
\end{tabular}

Note: Figures in the parentheses indicate percent increase over pre-ownership period.

*Farm size $=($ Own land+Rented in+Mortgaged in + Homestead+Orchard+Pond $)-$ (Rented out+Mortgaged out)

Source: Field survey, 2016

Impact on livestock resources: Due to the increased income of the LSPs that was earned from renting out the VMP for service, most livestock and poultry resources were increased to some extent during post-ownership period. 
Remarkable increase was found in the quantity and value of bullocks. The value of overall livestock \& poultry was increased by $11.2 \%$ (Table 5 ).

Table 5. Status of livestock resources before and after ownership of VMP

\begin{tabular}{|c|c|c|c|c|c|c|}
\hline \multirow{2}{*}{$\begin{array}{l}\text { Livestock and } \\
\text { poultry }\end{array}$} & \multicolumn{2}{|c|}{ After having VMP } & \multicolumn{2}{|c|}{ Before having VMP } & \multicolumn{2}{|c|}{ Mean difference } \\
\hline & $\begin{array}{l}\text { Quantity } \\
\text { (no.) }\end{array}$ & $\begin{array}{l}\text { Value } \\
\text { (Tk) }\end{array}$ & $\begin{array}{l}\text { Quantity } \\
\text { (No.) }\end{array}$ & $\begin{array}{l}\text { Value } \\
\text { (Tk) }\end{array}$ & $\begin{array}{l}\text { Quantity } \\
\text { (No.) }\end{array}$ & $\begin{array}{l}\text { Value } \\
\text { (Tk) }\end{array}$ \\
\hline \multirow[t]{2}{*}{ 1. Bull/Ox } & & & & \multicolumn{3}{|c|}{0.7} \\
\hline & 2.3 & 103500 & 1.7 & 72833 & $(40.0)$ & $30667(42.1)$ \\
\hline 2. Cow & 2.4 & 155056 & 2.3 & 151250 & $0.2(8.6)$ & $3806(2.5)$ \\
\hline 3. Calves & 2.3 & 56667 & 2.6 & 57400 & -0.3 & -733 \\
\hline 4. Goat & 3.0 & 16700 & 3.0 & 16556 & 0.0 & $144(0.9)$ \\
\hline 5. Duck (adult) & 3.6 & 988 & 3.5 & 931 & $0.1(3.6)$ & $56(6)$ \\
\hline 6. Chicken (adult) & 11.7 & 2654 & 13.0 & 2850 & -1.3 & -196 \\
\hline All types & 25.5 & 335563 & 26.0 & 301820 & -0.6 & 33743 (11.2) \\
\hline
\end{tabular}

Figures in the parentheses indicate percent increase over pre-ownership period.

Source: Field survey, 2016

Table 6. Annual income of local service providers before and after ownership of VMP

\begin{tabular}{|c|c|c|c|c|}
\hline Income Source & $\begin{array}{l}\text { After having } \\
\text { VMP (Tk) }\end{array}$ & $\begin{array}{c}\text { Before having VMP } \\
(\mathrm{Tk})\end{array}$ & $\begin{array}{c}\text { Mean } \\
\text { difference }\end{array}$ & $\begin{array}{c}\mathrm{P}(\mathrm{T}<=\mathrm{t}) \\
\text { value }\end{array}$ \\
\hline 1. Crop production & $405856(65.0)$ & $341308(73.7)$ & 64549 & \\
\hline Rice & 139900 & 136872 & 3028 & 0.96 \\
\hline Wheat & 122870 & 94698 & 28172 & 0.80 \\
\hline Jute & 14422 & 14172 & 250 & 0.98 \\
\hline Maize & 52856 & 50300 & 2556 & 0.95 \\
\hline Pulses & 41350 & 15157 & 26193 & 0.32 \\
\hline Oilseed & 11931 & 10108 & 1822 & 0.75 \\
\hline Vegetables & 16806 & 13917 & 2889 & 0.73 \\
\hline Crop residue & 5722 & 6083 & -361 & 0.89 \\
\hline 2. Livestock & $45556(7.3)$ & $33667(7.3)$ & 11889 & 0.41 \\
\hline 3. Poultry & $294(0.0)$ & $59(0.0)$ & 235 & 0.35 \\
\hline 4. Farm machinery & $63806(10.2)$ & 8889 (1.9) & $54917 * * *$ & 0.005 \\
\hline 5. Fishery & $42118(6.7)$ & $42118(9.1)$ & 0 & 1.00 \\
\hline 6. Service & $23800(3.8)$ & $23244(5.0)$ & 556 & 0.97 \\
\hline 7. Business & $43222(6.9)$ & $13778(3.0)$ & 29444 & 0.34 \\
\hline Total income & $6,24,651(100)$ & $4,63,062(100)$ & 1,61,589 & \\
\hline
\end{tabular}

Note: $* * *$ indicate significant at $1 \%$ level; Figures within parentheses are the percentages of total income.

Source: Field survey, 2016 
Impact on household income: The principal components of household income of the LSPs were crop farming, livestock, farm machinery, fisheries, business, and services. The annual household income of the LSP was increased by $34.9 \%$ during post-ownership period of VMP. In the post-ownership period of VMP, the percent increase in income was only significant in case of farm machineries (618 $\%$ ). The LSP earned $10.2 \%$ of total income from custom hiring of VMP services (Table 6).

Impact on household assets: Due to increased income, the housing assets of all LSPs of VMP increased to some extent. They have made good improvements in their dwelling and kitchens during the post-ownership period. Table 7 revealed that the number and value of Pacca building were increased by $133 \%$ and $43 \%$, respectively, during post-ownership period. Improvement was also found in the value of Pacca kitchen. Some of the LSPs of VMP have constructed more valuable storehouses due to increase of crop production.

Table 7. Type of houses owned by LPSs before and after ownership of VMP

\begin{tabular}{l|cr|r|r|c|c}
\hline & \multicolumn{2}{|c|}{ After having VMP } & \multicolumn{2}{c|}{ Before having VMP } & \multicolumn{2}{c}{ Mean difference } \\
\cline { 2 - 7 } & Quantity & Value (Tk) & Quantity & Value (Tk) & Quantity & Value (Tk) \\
\hline 1. Dwelling house & $\mathbf{2 . 2 2}$ & $\mathbf{3 8 2 9 7 2}$ & $\mathbf{1 . 9 4}$ & $\mathbf{2 8 0 4 1 7}$ & $\mathbf{0 . 2 8}(\mathbf{1 4 . 3})$ & $\mathbf{1 0 2 5 5 6}(\mathbf{3 6 . 6})$ \\
Pacca $^{I}$ & 0.39 & 222556 & 0.17 & 155556 & 0.22 & 67000 \\
Semi-pacca $^{2}$ & 1.06 & 139444 & 0.94 & 102778 & 0.11 & 36667 \\
Katcha-pacca $^{3}$ & 0.78 & 20972 & 0.83 & 22083 & -0.06 & -1111 \\
2. Kitchen & $\mathbf{1 . 0 6}$ & $\mathbf{3 0 4 1 7}$ & $\mathbf{1 . 0 0}$ & $\mathbf{2 4 6 9 4}$ & $\mathbf{0 . 0 6}(\mathbf{5 . 6})$ & $\mathbf{5 7 2 2}(\mathbf{2 3 . 2})$ \\
Pacca & 0.17 & 23056 & 0.17 & 17500 & 0.00 & 5556 \\
Semi-pacca & 0.11 & 1667 & 0.11 & 1667 & 0.00 & 0 \\
Katcha-pacca & 0.78 & 5694 & 0.72 & 5528 & 0.06 & 167 \\
3. Other houses & $\mathbf{1 . 8 9}$ & $\mathbf{8 1 4 4 4}$ & $\mathbf{1 . 6 7}$ & $\mathbf{7 4 6 3 9} \mathbf{0 . 2 2}(\mathbf{1 3 . 3})$ & $\mathbf{6 8 0 6}(\mathbf{9 . 1})$ \\
Cowshed & 0.83 & 31444 & 0.78 & 26389 & 0.06 & 5056 \\
Poultry shed & 0.56 & 1056 & 0.50 & 472 & 0.06 & 583 \\
Store house & 0.50 & 48944 & 0.39 & 47778 & 0.11 & 1167 \\
\hline
\end{tabular}

Note: ${ }^{1}$ House with concrete roof and brick wall.

${ }^{2}$ House with corrugated iron (CI) sheet roof and brick wall.

${ }^{3}$ House with CI sheet roof and thrashed bamboo/jute stick/straw wall.

Figures in the parentheses indicate percent increase over pre-ownership period.

Source: Field survey, 2016

Providing planting services by VMP had a major impact in increasing the household assets in the study areas. Table 8 shows the comparative scenarios of the household asset positions of VMP LSPs. The quantity and quality (in terms of value) of different types of furniture and modern amenities of the LSP were 
increased after having VMP. Among different types of furniture, the highest increase was recorded in the number of dining tables and showcases $(42.9 \%)$. However, the quantity and value of overall furniture were increased by $23 \%$ and $19 \%$, respectively. Again, the highest increase was reported in the number of mobile phones $(44.7 \%)$ and motor cycles $(25 \%)$ among modern amenities. However, the number and value to modern amenities were increased by $25.2 \%$ and $45.5 \%$, respectively.

Impact on food intake: Due to increase in income from renting out VMP service to others, the frequency and quality of food intake were significantly increased in the study areas. One of the highest improvements was reported in the case of weekly intake of fish. Meat intake also increased remarkably (Table 9).

Table 8. Household assets of LSPs before and after ownership of VMP

\begin{tabular}{l|c|r|r|r|r|r|r|r}
\hline \multirow{2}{*}{ Household assets } & \multicolumn{2}{|c|}{$\begin{array}{c}\text { After having } \\
\text { VMP }\end{array}$} & \multicolumn{2}{c|}{$\begin{array}{c}\text { Before having } \\
\text { VMP }\end{array}$} & \multicolumn{2}{c|}{ Mean difference } & \multicolumn{2}{c}{$\begin{array}{c}\text { \% increase over } \\
\text { pre-ownership }\end{array}$} \\
\cline { 2 - 10 } & $\begin{array}{c}\text { Quantity } \\
\text { (No.) }\end{array}$ & $\begin{array}{c}\text { Value } \\
\text { (Tk) }\end{array}$ & $\begin{array}{c}\text { Quantity } \\
\text { (No.) }\end{array}$ & $\begin{array}{c}\text { Value } \\
\text { (Tk) }\end{array}$ & $\begin{array}{c}\text { Quantity } \\
\text { (No.) }\end{array}$ & $\begin{array}{c}\text { Value } \\
\text { (Tk) }\end{array}$ & Quantity & Value \\
\hline 1. Furniture & $\mathbf{2 0 . 2 2}$ & $\mathbf{9 3 7 8 3}$ & $\mathbf{1 6 . 4 4}$ & $\mathbf{7 8 8 0 8}$ & $\mathbf{3 . 7 8}$ & $\mathbf{1 4 9 7 5}$ & $\mathbf{2 3 . 0}$ & $\mathbf{1 9 . 0}$ \\
Cot $($ Khat $)$ & 2.50 & 32417 & 2.06 & 25722 & 0.44 & 6694 & 21.6 & 26.0 \\
Chowki & 1.50 & 4750 & 1.67 & 3861 & -0.17 & 889 & -10.0 & 23.0 \\
Almirah & 1.39 & 18739 & 1.17 & 16878 & 0.22 & 1861 & 19.0 & 11.0 \\
Dining table & 1.11 & 7611 & 0.78 & 6500 & 0.33 & 1111 & 42.9 & 17.1 \\
Table & 2.17 & 5822 & 1.78 & 5172 & 0.39 & 650 & 21.9 & 12.6 \\
Chair & 6.44 & 4878 & 4.56 & 3258 & 1.89 & 1619 & 41.5 & 49.7 \\
Bench & 0.33 & 156 & 0.28 & 144 & 0.06 & 11 & 20.0 & 7.7 \\
Dress-stand & 1.89 & 2356 & 1.67 & 2133 & 0.22 & 222 & 13.3 & 10.4 \\
Trunk/big box & 1.78 & 7972 & 1.72 & 7694 & 0.06 & 278 & 3.2 & 3.6 \\
Showcase & 1.11 & 9083 & 0.78 & 7444 & 0.33 & 1639 & 42.9 & 22.0 \\
2. M. amenities & $\mathbf{9 . 6 5}$ & $\mathbf{1 0 9 7 4 2}$ & $\mathbf{7 . 7 2}$ & $\mathbf{7 5 4 3 1}$ & $\mathbf{1 . 9 4}$ & $\mathbf{3 4 3 1 1}$ & $\mathbf{2 5 . 2}$ & $\mathbf{4 5 . 5}$ \\
Cell phone & 3.06 & 23122 & 2.11 & 18139 & 0.94 & 4983 & 44.7 & 27.5 \\
Motor cycle & 0.56 & 65556 & 0.44 & 39556 & 0.11 & 26000 & 25.0 & 65.7 \\
Bi-cycle & 0.83 & 3361 & 0.67 & 2500 & 0.17 & 861 & 25.0 & 34.4 \\
Television & 1.17 & 13833 & 1.17 & 11833 & 0.00 & 2000 & 0.0 & 16.9 \\
Wrist watch & 0.67 & 1061 & 0.61 & 1061 & 0.06 & 0 & 9.1 & 0.0 \\
Wall clock & 1.89 & 1978 & 1.44 & 1811 & 0.44 & 167 & 30.8 & 9.2 \\
Flash light & 1.50 & 831 & 1.28 & 531 & 0.22 & 300 & 17.4 & 56.5 \\
\hline
\end{tabular}

${ }^{1}$ a four legged wooden bedstead

Source: Field survey, 2016

Impact on LSP's livelihood status: Among different livelihood status indicators, a remarkable change was found in the societal membership of the LSPs during 
post-ownership period. Table 10 revealed that the membership of LSP with local level social organizations increased by $255 \%$ in the study areas. The use of toilet tissues were also increased to some extent. It was also reported that better economic standing enabled them to buy more costly new clothes for several social and religious events.

Table 9. Food intake pattern of LSPs after ownership of VMP

\begin{tabular}{l|c|c|c|c}
\hline \multirow{2}{*}{ Food intake pattern } & \multicolumn{2}{|c|}{ Frequency of food intake } & \multirow{2}{*}{$\begin{array}{c}\text { Mean } \\
\text { difference }\end{array}$} & $\begin{array}{c}\text { P(T<=t) } \\
\text { value }\end{array}$ \\
\cline { 2 - 3 } $\begin{array}{c}\text { After having } \\
\text { VMP }\end{array}$ & $\begin{array}{c}\text { Before } \\
\text { having VMP }\end{array}$ & 0.0 & 1.00 \\
\hline 1. Food intake (times/day) & 3.0 & 3.0 & $1.4^{* * *}$ & 0.007 \\
2. Fish intake (time/week) & 3.7 & 2.3 & $1.5^{*}$ & 0.11 \\
3. Meat intake (time/month) & 5.6 & 4.1 & 0.3 & 0.60 \\
4. Egg intake (time/week) & 2.5 & 2.2 & 0.1 & 1.00 \\
5. Milk intake (time/week) & 5.2 & 5.1 & 0.5 & 0.40 \\
6. Vegetable intake (kg/week) & 5.6 & 5.1 &
\end{tabular}

Note: $* * *$ and $*$ indicate significant at $1 \%$ and $10 \%$ level, respectively.

Source: Field survey, 2016

Table 10. Livelihood status of LSPs before and after ownership of VMP

\begin{tabular}{|c|c|c|c|}
\hline \multirow[b]{2}{*}{ Livelihood criteria } & \multicolumn{2}{|c|}{$\%$ of respondent's opinion } & \multirow{2}{*}{$\begin{array}{l}\% \text { increase over } \\
\text { pre-ownership }\end{array}$} \\
\hline & $\begin{array}{l}\text { After having } \\
\text { VMP }\end{array}$ & $\begin{array}{c}\text { Before having } \\
\text { VMP }\end{array}$ & \\
\hline 1. Use tube well water & 100 & 100 & 0.0 \\
\hline 2. Use sanitary toilet & 100 & 100 & 0.0 \\
\hline 3. Use toilet tissue & 100 & 89 & 12.4 \\
\hline 4. Adopt contraceptive method & 100 & 100 & 0.0 \\
\hline 5. Sending children to school & 100 & 100 & 0.0 \\
\hline 6. Consultation with MBBS doctor & 100 & 100 & 0.0 \\
\hline 7. Offer gifts in social events & 100 & 100 & 0.0 \\
\hline 8. Societal membership & 78 & 22 & 255 \\
\hline
\end{tabular}

Source: Field survey, 2016

\section{Overall Impacts of VMP on LSP's Livelihood}

The LPSs of the study areas were asked to mention the benefits received from custom hiring of VMP service. In this regard, $78 \%$ of LSPs opined that they gained popularity and honour from farmers. Due to receiving extra income from custom hiring services through VMP, about $67 \%$ of LSPs referred to their financial improvement and $28 \%$ commented on the improvement of food intake standard of their families. Twenty eight percent of LSPs were able to get 
additional crop lands through mortgage and $22 \%$ could build new houses through VMP incomes. It was also possible for some LSPs to start livestock farming and continue children's education due to this custom hiring business (Table 11).

Table 11. Overall impacts of VMP on LSP's livelihood

\begin{tabular}{l|c|c}
\hline \multicolumn{1}{c|}{ Type of impact } & Frequency & \% of respondent \\
\hline 1. Get popularity in the locality & 14 & 78 \\
2. Improve financial status of the family & 12 & 67 \\
3. Improve food intake standard & 5 & 28 \\
4. Get crop lands under mortgage & 5 & 28 \\
5. Build new house & 4 & 22 \\
6. Start livestock farming & 3 & 17 \\
7. Continuation of children's education & 3 & 17 \\
8. Others* & 3 & 17 \\
\hline
\end{tabular}

* Other impacts include repayment of loan, buy motor cycle, mitigate cost of crop cultivation, etc

Source: Field survey, 2016

\section{Challenges encountered by LSPs}

Although renting out of VMP service was profitable, the LSP encountered some challenges which were related to VMP generation 9. The VMP machine generally performs well in the sandy-loam and alluvial soils, but not in the wet soil condition. However, the VMP was developed for dry land crop cultivation. By contrast, 2WT are used to wet soil tillage and puddling soil for rice and while $61 \%$ of LSPs mentioned this as a problem, they may not have realistic expectations. Seating arrangement on machine is important in reducing drudgery of the LSP. Walking behind the VMP was not preferred by LSP. Fifty six percent LSP noted that there was no seating arrangement on the machine during ploughing. Since version 14, the VMP is fitted with a seating arrangement for road transportation and operating in longer fields. Since the VMP can only plant 4 rows per pass, it requires longer time to complete planting and seeding operations. The $12 \mathrm{hp}$ engine of $2 \mathrm{WTs}$ is unable to pull more than 4 furrows/lines in a single pass. Presently, the population of the VMP is low, so many farmers does not know about the benefit of VMP use: that was another crucial problem for LSP in the study areas. Some LSPs $(17 \%)$ reported that trained and skilled drivers are scarce, especially in the peak season (Rabi season). Seventeen percent of LSPs claimed that the weight of VMP machine is high (Table 12). Later versions of the VMP have reduced weight. 
Table 12. Challenges encountered by local service providers of VMP

\begin{tabular}{l|c|c}
\hline \multicolumn{1}{c|}{ Type of problem } & Frequency & \% of respondent \\
\hline $\begin{array}{l}\text { 1. Unable to use this machine in the wetland } \\
\text { 2. No seating arrangement on the machine during }\end{array}$ & 11 & 61 \\
ploughing & 10 & 56 \\
3. Relatively slow operation to complete planting & 9 & 50 \\
4. Farmers' lack of knowledge on the benefit of VMP & 8 & 44 \\
5. Shortage of trained and skilled driver & 3 & 17 \\
6. Heavy weight of VMP machine & 3 & 17 \\
7. Others* & 5 & 28 \\
\hline
\end{tabular}

* Other problems include lack of spear parts, irregularity in seed/fertilizer dropping, unable to use all fertilizers together, lack of power tiller, higher cost compared to PTOS, etc

Source: Field survey, 2016

\section{Suggestions Provided by LSPs}

Respondent LSPs provided some suggestions for wider adoption of VMP in the study areas. Seventy eight percent of LSPs suggested that VMP machine should be popularized among farmers and power tiller owners through conducting field days and demonstrating the performance of VMP. A good number of LSPs opined that the price of VPM is still too high. Therefore, they suggested reducing its price or giving more subsidies on its price so that farmers and LSPs can buy it easily. Some LSPs suggested redesigning the machine with seating arrangement (this has been accomplished in more recent versions of the VMP) and make it applicable for wet condition. The advantages of Conservation Agriculture remain unknown to most of the farmers. In this sense $28 \%$ of LSPs requested the concerned the Department of Agricultural Extension to provide training on CA for farmers. Wider adoption of the VMP mostly depends on skilled and experienced drivers. Seventeen percent of LSPs suggested that hands-on training on VMP operations should be arranged for power tiller drivers on a continuous basis. Some LSPs also suggested providing bank loan for purchasing VMP machine with easy terms and condition (Table 13).

Table 13. Local service provider's suggestions for wider adoption of VMP

\begin{tabular}{l|c|c}
\hline \multicolumn{1}{c|}{ Suggestion } & Frequency & \% of respondent \\
\hline 1. Arrange field days/demonstrate VMP performance & 14 & 78 \\
2. Reduce the price of VMP/Continue subsidy on VMP & 11 & 61 \\
3. Redesign the machine with seating arrangement & 8 & 44 \\
4. Redesign the machine for operating in wetland & 6 & 33 \\
5. Arrange CA awareness training for farmers & 5 & 28 \\
6. Arrange skill training for LSP & 3 & 17 \\
7. Provide bank loan with easy terms and condition & 3 & 17 \\
\hline
\end{tabular}

Source: Field survey, 2016 


\section{Conclusions and Recommendations}

The study assessed the annual use pattern and profitability of VMP operations and its impacts on LSP's livelihood. The VMP can be used for 12 months in a year, but the highest use occurs in the rabi season. The custom hiring of VMP services is a profitable business in the study areas. The payback period and annual break-even size of land were less than a year (0.72 year) and 7.79 ha, respectively. This custom hiring business has made some improvements in the livelihoods of the LSPs of VMP. The incomes from custom hiring business are mostly spent on land mortgage, livestock purchase, construction of houses, purchase of furniture \& modern amenities, and purchase of dietary fish \& meat that indicate higher standard of living of LSP and their families. Besides, most LSPs gain honour from farmers and popularity in the locality. Although renting out VMP service was profitable, it is constrained by some minor problems, no seating arrangement on the machine during ploughing, slow planting operation time, heavy weight, and lack of trained drivers.

Financial support and technical assistance regarding VMP should be made available by the government or by NGO for LSP and local manufacturers, and redesign (if possible) of the machine for the higher adoption of VMP in the study areas. In addition, necessary steps should be taken for raising farmers' awareness toward CA farming and developing skilled drivers of VMP for wider adoption of this machine.

Acknowledgement: The financial assistance to carry out the study from LWR2010-080 Project funded by Australian Centre for International Agricultural Research (ACIAR) through Murdoch University, Australia is greatly acknowledged. We also appreciate the help of many others; both individuals and institutions, during conducting this study and regret our inability to acknowledge them all individually.

\section{References}

Alamgir, M. A., M. M. Uddin, T. P. Tiwari and F. Marufa. 2015. Performance of wheat varieties under different tillage systems in Bangladesh, Conference on International Research on Food Security, Natural Resource Management and Rural Development organized by the Humboldt-Universität $\mathrm{zu}$ Berlin and the Leibniz Centre for Agricultural Landscape Research (ZALF), Tropentag 2015, Berlin, Germany, September 16-18, 2015.

BBS, 2018. Statistical Yearbook of Bangladesh. Bangladesh Bureau of Statistics, Ministry of Planning, Dhaka, Bangladesh.

BER, 2018. Bangladesh Economic Review. Economic Adviser's Wing, Finance Division, Ministry of Finance, Government of the People's Republic of Bangladesh, December 2018.

Barma, N.C.D., P. K. Malaker, Z. I. Sarker, M. A. Khaleque, M. Israil Hossain, M.A.Z. Sarker, M. Bodruzzaman, M.A Hakim, and A. Hossain. 2014. Adoption of power tiller operated seeder in rice wheat cropping system. WRC, BARI Annual report, Nashipur, Dinajpur. pp: 248-253.

Bell, R.W., Haque, M.E., Johansen, C., Vance, W., Kabir, M.E., Musa, M.A., Mia, M.N.N., Neogi, M.G. and Islam, M.A. 2017. Mechanised minimum soil disturbance 
establishment and yield of diverse crops in paddy fields using a two-wheel tractormounted planter for smallholder cropping. Experimental Agriculture, 54 (5): 755-773.

Haque, M.E., Bell, R.W., Jahiruddin, M., Hossain, M.M., Rahman, M.M., Begum, M., Hossen, M.A., Salahin, N., Zahan, T., Hossain, M.M., Hashem, A., Islam, M.A., Vance, W.H., Hossain, M.I., Esdaile, R.J. and Kabir, M.E. 2018. Manual for smallholders' conservation agriculture in Rice-based systems. Murdoch University. $\begin{array}{llll}\text { Murdoch University. } & \text { p } & 108 . & \text { https://researchrepository. }\end{array}$ murdoch.edu.au/id/eprint/41693/

Haque, M.E., Islam, A.K.M.S., Hossain, M.M., Bell, R.W. and Sayre, K.D. 2017. An innovative versatile multi-crop planter for crop establishment using two-wheel tractors. AMA - Agricultural Mechanization in Asia, Africa and Latin America, 48 (4):33-37

Haque, M.E., Bell, R.W., Kassam, A. and Mia, M.N.N. 2016. Versatile strip seed drill: A 2-wheel tractor-based option for smallholders to implement conservation agriculture in Asia and Africa. Environments, 3(1):1-13. Doi: 10.3390/environments3010001.

Haque, M.E., R.W. Bell, A.K.M.S. Islam, K. Sayre, M.M. Hossain. 2011. Versatile multi-crop planter for two-wheel tractors: an innovative option for smallholders. In: $5^{\text {th }}$ world Congress of Conservation Agricultural. 26-29 September 2011, Brisbane, Australia, Pp.120-103.

Hossain, M. I., M. N. A. Siddiqui, G. M. Panaullah, J. M. Duxbury and J. G. Lauren. 2014. Raised beds: A resource conserving technology for improved crop production in Bangladesh. A booklet under Cornell University-Food for progress programme in Bangladesh.

Islam, A.K.M., M.E. Haque, M.M. Hossain, M.A. Saleque, and R.W. Bell. 2010. Water and fuel saving technologies: Unpuddled bed and strip tillage for wet season rice cultivation in Bangladesh. 19th World Congress of Soil Science, Soil Solutions for a Changing World, 1-6 August 2010, Brisbane, Australia.

Johansen, C.J., Haque, M.E., Bell, R.W., Thierfelder, C. and Esdaile, R.J., 2012. Conservation agriculture for small holder rainfed farming: Opportunities and constraints of new mechanized seeding systems. Field Crops Research 132:18-32. doi:10.1016/j.fcr.2011.11.026.

Miah M.A.M and M. E. Haque. 2015. Farm level impact study of power tiller operated seeder on service providers' livelihood in some selected sites of Bangladesh. Bangladesh J. Agril. Res. 40(4): 669-682.

Miah, M. A. M., M. E. Haque, M. E. Baksh, and M. I. Hossain. 2010. Economic analysis of power tiller operated seeder operations at farm level, Journal of Agricultural Engineering 38/AE(1): 19-24.

Roy K. C., M. E. Haque, S. E. Justice, M. I. Hossain, C. A. Meisner. 2009. Development of agriculture tillage machinery for conservation agriculture in Bangladesh. Agricultural Mechanization in Asia, Africa and Latin America 40: 58-64.

Sarker, K.K., W. Xiaoyan, L. Hongwen, X. Chunlin, L. Wenying, H. Jin, E. R. Jeff, R.G. Rasaily, and Q. Xiaodong. 2012. Development strategies of small scale conservation farming practices on two wheeled tractor in Bangladesh, African Journal of Agricultural Research 7(26): 3747-3756.

Wohab, M.A., Roy, K.C., Haque, M.E., Abedin, M.J., Islam, M.S. 2007. Field performance evaluation of BHT seeder for sowing and tilling. J. Socio. Res. Dev. 4(3): 116-119. 
Appendix 1. Profitability of VMP operation at farm level

\begin{tabular}{l|c|c|c}
\hline \multicolumn{1}{c|}{ Particular } & $\begin{array}{c}\text { Only VMP } \\
\text { income (subsidy } \\
\text { on VMP) }\end{array}$ & $\begin{array}{c}\text { Only VMP } \\
\text { income (No } \\
\text { subsidy on VMP) }\end{array}$ & $\begin{array}{c}\text { Only tillage } \\
\text { income with } \\
\text { PT }\end{array}$ \\
\hline A. Gross return (Tk/year) & $\mathbf{7 1 , 0 9 2}$ & $\mathbf{7 1 , 0 9 2}$ & $\mathbf{2 1 3 1 9 7}$ \\
Area under tillage (ha/LSP) & 21.721 & 21.721 & 36.43 \\
Rental charge of VMP/PT (Tk/ha) & 3272.95 & 3272.95 & 5852 \\
B. Variable cost (Tk/year) & $\mathbf{2 8 5 1 7}$ & $\mathbf{2 8 5 1 7}$ & $\mathbf{9 1 2 9 9}$ \\
Fuel and oil & 17,884 & 17,884 & 81732 \\
Wage for driver & 7,922 & 7,922 & 8046 \\
Repair and maintenance & 1,017 & 1,017 & 504 \\
Spare parts & 1,694 & 1,694 & 1017 \\
C. Fixed cost (Tk/year) & $\mathbf{1 7 6 5 2}$ & $\mathbf{2 3 9 5 2}$ & $\mathbf{1 1 3 5 2}$ \\
Depreciation on power tiller (PT) & 2,193 & 2,193 & 2193 \\
Depreciation on VMP/plough & 2,700 & 5,400 & 0 \\
Depreciation on machinery shed & 386 & 386 & 386 \\
Interest on investment (VMP+PT) & 12,373 & 15,973 & 8773 \\
D. Total cost (Tk/year) & $\mathbf{4 6 1 6 9}$ & $\mathbf{5 2 4 6 9}$ & $\mathbf{1 0 2 6 5 1}$ \\
E. Gross margin (Tk/year) & 42575 & 42575 & 121898 \\
F. Net return (Tk/year) & 24923 & 18623 & 110546 \\
G. Rate of return (BCR) & & & \\
Over variable cost & 2.49 & 2.49 & 2.34 \\
Over total cost & 1.54 & 1.35 & 2.08 \\
H. Payback period (PT+VMP) & $\mathbf{4 . 1 4}$ & $\mathbf{7 . 1 5}$ & $\mathbf{0 . 6 6}$ \\
(year) & & & \\
\hline Not Pice & & & \\
\hline
\end{tabular}

Note: Price of VMP = Tk. 60,000; Subsidized price of VMP = Tk. 30,000; Average price of PT $=$ Tk. 73,111 (including ploughing machine); Diesel cost for intensive tillage $(\mathrm{Tk} / \mathrm{ha})=$ Tk.2243.54; Diesel cost for minimum tillage $(\mathrm{Tk} / \mathrm{ha})=\mathrm{Tk}$. 823.33; Interest rate $=$ Tk.12/year; Life of VMP \&PT $=10$ years; Salvage value of PT \& $\mathrm{VMP}=10 \%$ of their purchase prices; Depreciation $=12$ months for VMP \& PT

Conversion rate $=1 \mathrm{US} \$=81 \mathrm{BDT}$;

Figures in the parentheses are percentages of the total cost.

Source: Field survey, 2016. 